\title{
Analisis Tingkat Kesehatan Kinerja Keuangan Perusahaan BUMN Bidang Industri Pertahanan (Indhan) Indonesia Periode 2015-2019
}

Analysis of the health level of the financial performance at BUMN owned company in the defense industry (Indhan) Indonesia period 2015-2019

\section{Angga Nugraha}

Program Studi D3 Keuangan dan Perbankan, Politeknik Negeri Bandung

E-mail: angga.nugraha.kepn17@polban.ac.id

\section{Tjetjep Djuwarsa}

Jurusan Akuntansi, Politeknik Negeri Bandung

E-mail: tjetjepdjuwarsa485@gmail.com

\section{Ine Mayasari}

Jurusan Akuntansi, Politeknik Negeri Bandung

E-mail: ine.mayasari@polban.ac.id

\begin{abstract}
This study seeks to describe the quality of financial performance of Indonesian Defense Industry (Indhan) BUMN companies in the 2015-2019 period as measured using a reference standard based on the Decree of the Minister of State-Owned Enterprises (BUMN) Number (KEP-100/MBU/2002). The assessment indicators used as an assessment tool consist of 8 indicators, namely Return on Equity, Return on Investment, cash ratio, current ratio, collection periods, inventory turnover, total asset turnover, and the ratio of total equity to total assets. The results of the study showed varied results. PT Dahana (Persero) obtained a "Sehat AA" level of financial health in 2015-2018 and "Sehat A" in 2019. PT Industri Telekomunikasi Indonesia (Persero) obtained a "Kurang Sehat B" level of financial health in 2015-2016, then in 2017 received $a^{\prime \prime K u r a n g ~ S e h a t ~ B B " ~ t o ~ d e c r e a s e ~ i n ~} 2018$ and 2019 to "Tidak Sehat CCC". PT Pindad (Persero) obtained financial performance results with a value of "Kurang Sehat BBB" in 2015-2017, then "Sehat A" in 2018 and decreased in 2019 to "Kurang Sehat BBB".
\end{abstract}

Keywords: financial performance, BUMN, defense industry, financial ratio

\section{Pendahuluan}

Indonesia sebagai negara kepulauan yang besar, memiliki pengalaman sejarah yang panjang tentang arti penting pertahanan keamanan sebuah negera. Setelah sebelumnya berjaya di era kerajaan dan kesultanan, Indonesia mendapat terjangan cobaan dengan masuknya penjajah yang berlangsung dalam kurun waktu 350 tahun oleh Belanda dan disusul 3,5 tahun tahun oleh Jepang hingga berakhir pada 9 Ramadhan 1364H/17 Agustus 1945M dengan ditandai proklamasi kemerdekaan Indonesia yang diwakili oleh Ir. Soekarno dan Moh. Hatta atas nama bangsa Indonesia.

Sistem pertahanan negara adalah sistem pertahanan yang bersifat semesta melibatkan seluruh warga negara, wilayah, dan sumber daya nasional lainnya, serta dipersiapkan secara dini oleh pemerintah dan diselenggarakan secara total, terpadu, terarah, dan berlanjut untuk menegakkan kedaulatan negara, keutuhan wilayah, dan keselamatan segenap bangsa dari segala ancaman 
(Undang-Undang Nomor 3 Tahun 2002 tentang Pertahanan Negara Pasal 1 Angka 2).

Secara garis besar, sistem pertahanan Indonesia dibagi ke dalam tiga bagian yakni sistem pertahanan darat, sistem pertahanan laut, dan sistem pertahanan udara. Pembangunan sistem pertahanan ini melibatkan beberapa aspek, diantaranya sumber daya manusia (SDM) dan teknologi pendukung. Dari sisi aspek sumber daya manusia, indonesia memiliki Tentara Nasional Indonesia (TNI) sebagai komponen utama dengan didukung oleh komponen cadangan dan komponen pendukung yang bertugas menghadapi ancaman yang bersifat militer (Ibid, Pasal 7).

Di samping pembangunan SDM, Indonesia juga mengerahkan usaha untuk melengkapi sistem pertahanan dengan membangun teknologi militer. Sebagai bagian dari pembangunan postur pertahanan negeri, pembangunan teknologi militer senantiasa berubah secara dinamis, sesuai dengan perubahan lingkungan strategis dengan berbagai prediksi ancaman yang muncul. Guna memenuhi hal tersebut, indonesia menempuh langkah usaha salah satunya dengan pembangunan industri pertahanan di dalam negeri. Industri pertahanan yang ada di Indonesia terbagi ke dalam dua bagian, yakni industri pertahanan milik negara (BUMN) dan industri pertahanan milik swasta.

Sejak diterbitkannya Undang-Undang Industri Pertahanan (UU No.16 Tahun 2012), pemerintah berkomitmen untuk membangun Industri Pertahanan yang mumpuni dan mampu bersaing. Hal ini diwujudkan secara bertahap dan didukung salah satunya melalui langkah kerjasama internasional. Upaya pemerintah ini pada dasarnya dilakukan dalam rangka meningkatkan kualitas militer Indonesia, mengingat peran industri militer memiliki andil penuh terhadap kebutuhan alat utama sistem pertahanan (alutsista) Indonesia.

Kemajuan suatu perusahaan dapat ditinjau salah satunya dari aspek keuangannya. Kinerja perusahaan diproyeksikan oleh setiap laporan keuangan perusahaan yang dari hal tersebut menggambarkan prestasi perusahaan di suatu periode. Berdasarkan laporan keuangan perusahaan, kita dapat mengukur keberhasilan kinerja perusahaan dalam mencapai rencana-rencana keuangannya.

Berikut ini merupakan ikhtisar keuangan beberapa perusahaan BUMN bidang Industri Pertahanan (Indhan) periode 2015-2019.

Tabel 1. Ikhtisar Kinerja Keuangan Perusahaan Objek Penelitian

\begin{tabular}{|r|l|r|r|r|r|r|r|}
\hline \multirow{2}{*}{ No } & \multicolumn{5}{|c|}{ Uraian } & \multicolumn{1}{c|}{2015} & \multicolumn{1}{c|}{ Tahun } \\
\hline \multicolumn{7}{|c|}{ PT Dahana (Persero) } \\
\hline 1 & Pendapatan Usaha & 1.376 .172 & 1.371 .655 & 1.550 .434 & 1.982 .661 & 1.989 .400 \\
\hline 2 & Beban Pokok Usaha & 1.062 .477 & 1.103 .778 & 1.251 .960 & 1.669 .229 & 1.727 .434 \\
\hline 3 & $\begin{array}{l}\text { Laba (Rugi) tahun } \\
\text { Berjalan }\end{array}$ & 89.071 & 82.099 & 125.257 & 133.964 & 74.098 \\
\hline 4 & Total Aset & 1.305 .839 & 1.254 .309 & 1.492 .078 & 1.795 .258 & 1.857 .671 \\
\hline 5 & Total Liabilitas & 704.039 & 9.874 & 5.824 & 853.734 & 855.862 \\
\hline 6 & Total Ekuitas & 601.800 & 678.689 & 801.111 & 941.523 & 1.001 .808 \\
\hline \multicolumn{7}{|c|}{ PT Industri Telekomunikasi Indonesia (Persero) } \\
\hline 1 & Pendapatan Usaha & 420.991 & 681.078 & 1.308 .680 & 847.756 & 395.377 \\
\hline 2 & Beban Pokok Usaha & 417.911 & 801.710 & 1.130 .519 & 549.177 & 380.990 \\
\hline 3 & $\begin{array}{l}\text { Laba (Rugi) Tahun } \\
\text { Berjalan }\end{array}$ & $(283.660)$ & $(316.198)$ & 6.610 & 462 & $(434.765)$ \\
\hline
\end{tabular}




\begin{tabular}{|r|l|r|r|r|r|r|}
\hline \multirow{2}{*}{ No } & \multicolumn{2}{|c|}{ Uraian } & \multicolumn{5}{c|}{ Tahun } \\
\cline { 3 - 7 } & & \multicolumn{1}{c|}{$\mathbf{2 0 1 5}$} & \multicolumn{1}{c|}{$\mathbf{2 0 1 6}$} & \multicolumn{1}{c|}{2017} & \multicolumn{1}{c|}{2018} & \multicolumn{1}{c|}{2019} \\
\hline 4 & Total Aset & 1.869 .763 & 1.366 .832 & 2.026 .983 & 1.829 .674 & 1.393 .342 \\
\hline 5 & Total Liabilitas & 1.345 .457 & 1.177 .084 & 1.812 .701 & 1.465 .635 & 1.661 .979 \\
\hline 6 & Total Ekuitas & 524.306 & 190.741 & 214.282 & 221.567 & $(268.637)$ \\
\hline \multicolumn{7}{|c|}{ PT Pindad (Persero) } \\
\hline 1 & Pendapatan Usaha & 1.948 .821 & 2.025 .443 & 2.456 .125 & 3.200 .897 & 3.398 .782 \\
\hline 2 & Beban Pokok Usaha & 1.545 .313 & 1.630 .496 & 1.835 .905 & 5.080 .465 & 5.426 .694 \\
\hline 3 & $\begin{array}{l}\text { Laba (Rugi) Tahun } \\
\text { Berjalan }\end{array}$ & 4.160 & 45.791 & 92.064 & 100.578 & 101.079 \\
\hline 4 & Total Aset & 4.072 .045 & 4.166 .618 & 5.961 .534 & 6.453 .286 & 6.889 .791 \\
\hline 5 & Total Liabilitas & 2.798 .828 & 2.907 .566 & 4.657 .364 & 2.405 .534 & 2.564 .734 \\
\hline 6 & Total Ekuitas & 1.273 .217 & 1.259 .052 & 1.304 .169 & 1.372 .820 & 1.465 .333 \\
\hline
\end{tabular}

Sumber : Laporan Keuangan Tahunan PT Dahana (Persero), PT INTI (Persero), dan PT Pindad (Persero) Periode 2015-2019.

Berdasarkan ikhtisar informasi keuangan di atas, kita dapat lihat tiga dari sekian perusahaan industri pertahanan dalam negeri di Indonesia memiliki ragam kualitas capaian usaha masingmasing.

PT Dahana sebagai industri pertahanan spesialiasi bidang pembuat bahan peledak tambang dan militer beserta PT Pindad yang bergerak di industri persenjataan TNI AD memiliki laju usaha yang menunjukkan angka laba setiap tahun pada 2015-2019. Berbanding terbalik dengan PT INTI, perusahaan ini dalam rentang waktu lima tahun kerap merugi sebanyak tiga kali yakni pada 2015, 2016, dan 2019 sehingga PT INTI pada tahun 2019 membukukan ekuitas negatif dikarenakan adanya rugi 435 milyar.

Dari capaian pendapatan usaha, PT Pindad memiliki trend yang kian meningkat setiap tahunnya dibanding PT Dahana dan PT INTI. PT Dahana memperoleh capaian pendapatan usaha yang meningkat pada tahun 2019, sedangkan PT INTI menunjukkan penurunan pendapatan usaha dibanding dua tahun sebelumnya.

Sebagai bentuk usaha mewujudkan cita-cita bersama baik di sisi pemerintah maupun di sisi perusahaan, maka diperlukan kegiatan evaluasi guna mengukur capaian prestasi yang telah diperoleh. BUMN dalam melakukan penilaian kinerja perusahaan, telah diatur dalam Surat Keputusan Menteri Badan Usaha Milik Negara (BUMN) Nomor: (KEP-100/MBU/2002) tentang Penilaian Tingkat Kesehatan Badan Usaha Milik Negara.

Berdasarkan uraian di atas, penulis tertarik untuk melakukan penelitian tentang "Analisis Tingkat Kesehatan Kinerja Keuangan Perusahaan BUMN Bidang Industri Pertahanan (Indhan) Indonesia Periode 2015-2019”.

\section{Kajian Pustaka}

\subsection{Manajemen Keuangan}

Manajemen keuangan adalah sebuah hal yang tentu ada lazimnya di suatu entitas bisnis maupun entitas non-bisnis. Manajemen keuangan didefinisikan sebagai kegiatan pengelolaan terhadap segenap fungsi keuangan organisasi. Seorang manajer keuangan memiliki tugas pokok yakni berusaha mencari serta mengalokasikan dana seefisien dan seefektif mungkin. 


\subsection{Laporan Keuangan}

Menurut Fahmi (2017), laporan keuangan ialah suatu informasi yang menggambarkan kondisi keuangan suatu perusahaan, dan lebih jauh informasi tersebut dapat dijadikan sebagai gambaran kinerja keuangan perusahaan.

Pada umumnya laporan keuangan terdiri dari tiga, diantaranya ialah Laporan Neraca/Posisi Keuangan, Laporan Laba-Rugi, dan Laporan Perubahan Modal/Laba Ditahan, Laporan Arus Kas, dan Catatan atas Laporan Keuangan (Notes).

\subsection{Perseroan Terbatas (PT)}

Perseroan Terbatas merupakan entitas bisnis yang modalnya terbagi atas sero (saham), serta beban tanggung jawab dari seorang pemegang saham perseroan terbatas didasarkan sesuai penyertaan modalnya masing-masing.

\subsection{Badan Usaha Milik Negara (BUMN)}

Badan Usaha Milik Negara, merupakan badan usaha yang modalnya secara dominasi atau total dimiliki negara melalui kepemilikan sero yang didanai dari kekayaan milik negera. BUMN dikatakan sebagai perusahaan BUMN Persero jika melakukan seluruh penyertaan atau sekurangkurangnya 51\% ekuitas bentuk sahamnya dimiliki oleh pemerintah yang berorientasi profit/laba.

\subsection{Evaluasi Sebagai Upaya Perbaikan}

Suatu penelitian yang dibuat guna menentukan rumusan aktivitas yang telah ditempuh perusahaan sehingga diperoleh gambaran kondisi capaian sebagai sarana untuk perbaikan rencana kerja periode berikutnya dikenal sebagai penelitian berjenis evaluasi. Upaya ini diperlukan perusahaan guna merumuskan rencana-rencana strategis guna meningkatkan dan memaksimalisasi kapabilitas yang dimiliki.

\subsection{Evaluasi Kinerja Perusahaan BUMN}

Perusahaan di dalam melakukan tindakan evaluasi kinerjanya memiliki berbagai cara baik yang bersifat teori baku yang berlaku secara umum maupun metode tersendiri yang ditetapkan perusahaan karena suatu pertimbangan tertentu, penilaian kinerja perusahaan dinilai berdasarkan kebijakan perusahaan masing-masing. Khusus untuk entitas bisnis pemerintah (BUMN), penilaian kinerja perusahaan diatur dalam Surat Keputusan (SK) Menteri BUMN No. (KEP100/MBU/2002) tentang Penilaian Tingkat Kesehatan Perusahaan BUMN. Penilaian kesehatan BUMN tersebut berlaku bagi perusahaan BUMN tak terkecuali dari perusahaan kelompok infra struktur maupun non infra struktur.

Berdasarkan Keputusan Menteri Badan Usaha Milik Negara Nomor: (KEP100/MBU/2002), perusahaan bidang industri pertahanan (Indhan) dikelompokkan sebagai perusahaan BUMN bidang Industri Strategis kategori BUMN non infrastruktur.

Penilaian kinerja perusahaan BUMN yang dipandu Surat Keputusan (SK) Menteri BUMN No. (KEP-100/MBU/2002) dibagi ke dalam 3 penilaian diantaranya:

1) Aspek Keuangan

2) Aspek Administrasi

3) Aspek Operasional

Hasil penilaian yang telah dilakukan kemudian dikategorikan ke dalam beberapa jenjang, sebagai berikut:

1) "SEHAT", kategori:

(AAA jika Total Skor $>95$ )

(AA jika $80<$ Total Skor $\leq 95$ ) 
(A jika $65<$ Total Skor $\leq 80$ )

2) “KURANG SEHAT”, kategori:

(BBB jika $50<$ Total Skor $\leq 65$ )

(BB jika $40<$ Total Skor $\leq 50$ )

(B jika $30<$ Total Skor $\leq 40$ )

3) “TIDAK SEHAT”, kategori:

$($ CCC jika $20<$ Total Skor $\leq 30$ )

$($ CC jika $10<$ Total Skor $\leq 20)$

(C jika Total Skor $\leq 10$ )

Pada penelitian kali ini akan khusus dilakukan menilai kualitas kesehatan aspek keuangan tanpa disertai 2 aspek lainnya (Operasional dan Administrasi), berikut indikator-indikator penilaiannya.

Aspek keuangan pada sistem penilaian berdasarkan SK Menteri BUMN No. (KEP100/MBU/2002) dihitung secara bertahap. Perhitungan tahap pertama yakni menghitung rasiorasio keuangan sebanyak delapan rasio, kemudian daei hasil perhitungan rasio tersebut dikelompokkan ke dalam range yang telah ditetapkan pedoman. Bobot terbaik penilaian tingkat kesehatan BUMN aspek keuangan jenis non infrastruktur ialah sebesar 70, rasio-rasio keuangan/indikator penilaian tingkat kesehatan keuangan ialah sebagai berikut:

1) Return on Equity (ROE)

Berikut rumus perhitungan untuk menganalisis Return on Equity:

$$
\mathrm{ROE}=\frac{\text { Laba Setelah Pajak }}{\text { Modal Sendiri }} \times 100 \%
$$

Berdasarkan perhitungan, maka dikonversikan angka hasil perhitungan sebagaimana tabel berikut.

Tabel 2. Daftar Skor untuk Rasio Imbalan Para Pemegang Sero/Saham

\begin{tabular}{|c|c|}
\hline ROE $\mathbf{( \% )}$ & SKOR \\
\hline $15<(\mathrm{ROE})$ & 20 \\
\hline $13<(\mathrm{ROE}) \leq 15$ & 18 \\
\hline $11<(\mathrm{ROE}) \leq 13$ & 16 \\
\hline $9<(\mathrm{ROE}) \leq 11$ & 14 \\
\hline $7,9<(\mathrm{ROE}) \leq 9$ & 12 \\
\hline $6,6<(\mathrm{ROE}) \leq 7,9$ & 10 \\
\hline $5,3<(\mathrm{ROE}) \leq 6,6$ & 8,5 \\
\hline $4<(\mathrm{ROE}) \leq 5,3$ & 7 \\
\hline $2,5<(\mathrm{ROE}) \leq 4$ & 5,5 \\
\hline $1<(\mathrm{ROE}) \leq 2,5$ & 4 \\
\hline $0<(\mathrm{ROE}) \leq 1$ & 2 \\
\hline$(\mathrm{ROE})<0$ & 0 \\
\hline
\end{tabular}


2) Return on Investment (ROI)

Berikut rumus perhitungan untuk menganalisis Return on Investment:

$$
\mathrm{ROI}=\frac{\text { EBIT }+ \text { Penyusutan }}{\text { Capital Employed }} \times 100 \%
$$

Berdasarkan perhitungan, maka dikonversikan angka hasil perhitungan sebagaimana tabel berikut.

Tabe1 3. Daftar Skor untuk Rasio Pengembalian Investasi

\begin{tabular}{|c|c|}
\hline ROI $\mathbf{~} \% \mathbf{)}$ & SKOR \\
\hline $18<(\mathrm{ROI})$ & 15 \\
\hline $15<(\mathrm{ROI}) \leq 18$ & 13,5 \\
\hline $13<(\mathrm{ROI}) \leq 15$ & 12 \\
\hline $12<(\mathrm{ROI}) \leq 13$ & 10,5 \\
\hline $10,5<(\mathrm{ROI}) \leq 12$ & 9 \\
\hline $9<(\mathrm{ROI}) \leq 10,5$ & 7,5 \\
\hline $7<(\mathrm{ROI}) \leq 9$ & 6 \\
\hline $5<(\mathrm{ROI}) \leq 7$ & 5 \\
\hline $3<(\mathrm{ROI}) \leq 5$ & 4 \\
\hline $1<(\mathrm{ROI}) \leq 3$ & 3 \\
\hline $0<(\mathrm{ROI}) \leq 1$ & 2 \\
\hline$(\mathrm{ROI})<0$ & 1 \\
\hline
\end{tabular}

3) Rasio Kas (Cash Ratio)

Berikut rumus perhitungan untuk menganalisis Rasio Kas:

$$
\text { Cash Ratio }=\frac{\text { Kas }+ \text { Bank }+ \text { SBJPen }}{\text { Current Liabilities }} \times 100 \%
$$

Berdasarkan perhitungan, maka dikonversikan angka hasil perhitungan sebagaimana tabel berikut.

Tabel 4. Daftar Skor untuk Cash Ratio

\begin{tabular}{|c|c|}
\hline Cash Ratio $\mathbf{( \% )}$ & SKOR \\
\hline$(\mathrm{x})>35$ & 5 \\
\hline $25 \leq(\mathrm{x})<35$ & 4 \\
\hline $15 \leq(\mathrm{x})<25$ & 3 \\
\hline $10 \leq(\mathrm{x})<15$ & 2 \\
\hline $5 \leq(\mathrm{x})<10$ & 1 \\
\hline $0 \leq(\mathrm{x})<5$ & 0 \\
\hline
\end{tabular}

4) Rasio Lancar (Current Ratio)

Berikut rumus perhitungan untuk menganalisis Rasio Lancar:

$$
\text { Current Ratio }=\frac{\text { Current Asset }}{\text { Current Liabilities }} \times 100 \%
$$


Berdasarkan perhitungan, maka dikonversikan angka hasil perhitungan sebagaimana tabel berikut.

Tabel 5. Daftar Skor Penilaian Rasio Lancar

\begin{tabular}{|c|c|}
\hline Current Ratio $(\%)$ & SKOR \\
\hline $125 \leq(\mathrm{x})$ & 5 \\
\hline $110 \leq(\mathrm{x})<125$ & 4 \\
\hline $100 \leq(\mathrm{x})<110$ & 3 \\
\hline $95 \leq(\mathrm{x})<100$ & 2 \\
\hline $90 \leq(\mathrm{x})<95$ & 1 \\
\hline$(\mathrm{x})<90$ & 0 \\
\hline
\end{tabular}

5) Collection Periods (CP)

Berikut rumus perhitungan untuk menganalisis Collection Periods:

$$
C P=\frac{\text { Total Piutang Usaha }}{\text { Pendapatan Usaha }} \times 365 \text { hari }
$$

Berdasarkan perhitungan, maka hasil angka dikonversikan ke dalam tabel berikut.

Tabel 6. Daftar Skor untuk rasio Perputaran Piutang (CP)

\begin{tabular}{|c|c|c|}
\hline Collection Periods (hari) & Perbaikan $=\mathbf{x}$ (hari) & SKOR \\
\hline$(C P) \leq 60$ & $(\mathrm{x})>35$ & 5 \\
\hline $60<(C P) \leq 90$ & $30<(\mathrm{x}) \leq 35$ & 4,5 \\
\hline $90<(\mathrm{CP}) \leq 120$ & $25<(\mathrm{x}) \leq 30$ & 4 \\
\hline $120<(\mathrm{CP}) \leq 150$ & $20<(\mathrm{x}) \leq 25$ & 3,5 \\
\hline $150<(\mathrm{CP}) \leq 180$ & $15<(\mathrm{x}) \leq 20$ & 3 \\
\hline $180<(\mathrm{CP}) \leq 210$ & $10<(\mathrm{x}) \leq 15$ & 2,4 \\
\hline $210<(\mathrm{CP}) \leq 240$ & $6<(\mathrm{x}) \leq 10$ & 1,8 \\
\hline $240<(\mathrm{CP}) \leq 270$ & $3<(\mathrm{x}) \leq 6$ & 1,2 \\
\hline $270<(\mathrm{CP}) \leq 300$ & $1<(\mathrm{x}) \leq 3$ & 0,6 \\
\hline $300<(\mathrm{CP})$ & $0<(\mathrm{x}) \leq 1$ & 0 \\
\hline
\end{tabular}

6) Perputaran Persediaan (PP)

Berikut rumus perhitungan untuk menganalisis PP:

$$
P P=\frac{\text { Total Persediaan }}{\text { Pendapatan Usaha }} \times 365 \text { hari }
$$

Berdasarkan perhitungan, maka dikonversikan angka hasil perhitungan sebagaimana tabel berikut.

Tabel 7. Daftar Skor untuk rasio PP

\begin{tabular}{|c|c|c|}
\hline $\begin{array}{c}\text { Perputaran Persediaan } \\
\text { (hari) }\end{array}$ & Perbaikan $=\mathbf{x}$ (hari) & SKOR \\
\hline$(\mathrm{PP}) \leq 60$ & $35<(\mathrm{x})$ & 5 \\
\hline $60<(\mathrm{PP}) \leq 90$ & $30<(\mathrm{x}) \leq 35$ & 4,5 \\
\hline
\end{tabular}




\begin{tabular}{|c|c|c|}
\hline $\begin{array}{c}\text { Perputaran Persediaan } \\
\text { (hari) }\end{array}$ & Perbaikan $=\mathbf{x}$ (hari) & SKOR \\
\hline $90<(\mathrm{PP}) \leq 120$ & $25<(\mathrm{x}) \leq 30$ & 4 \\
\hline $120<(\mathrm{PP}) \leq 150$ & $20<(\mathrm{x}) \leq 25$ & 3,5 \\
\hline $150<(\mathrm{PP}) \leq 180$ & $15<(\mathrm{x}) \leq 20$ & 3 \\
\hline $180<(\mathrm{PP}) \leq 210$ & $10<(\mathrm{x}) \leq 15$ & 2,4 \\
\hline $210<(\mathrm{PP}) \leq 240$ & $6<(\mathrm{x}) \leq 10$ & 1,8 \\
\hline $240<(\mathrm{PP}) \leq 270$ & $3<(\mathrm{x}) \leq 6$ & 1,2 \\
\hline $270<(\mathrm{PP}) \leq 300$ & $1<(\mathrm{x}) \leq 3$ & 0,6 \\
\hline $300<(\mathrm{PP})$ & $0<(\mathrm{x}) \leq 1$ & 0 \\
\hline
\end{tabular}

7) Total Assets Turn Over (TATO)

Berikut rumus perhitungan untuk menganalisis rasio perputaran dari total aset perusahaan:

$$
\text { TATO }=\frac{\text { Total Pendapatan }}{\text { Capital Employed }} \times 100 \%
$$

Berdasarkan perhitungan, maka dikonversikan angka hasil perhitungan sebagaimana tabel berikut.

Tabel 8. Daftar Skor untuk rasio TATO

\begin{tabular}{|c|c|c|}
\hline TATO $(\mathbf{\%})$ & $\begin{array}{c}\text { Perbaikan }=\mathbf{x} \\
\mathbf{( \% )}\end{array}$ & SKOR \\
\hline $120<($ TATO $)$ & $35<(\mathrm{x})$ & 5 \\
\hline $105<($ TATO $) \leq 120$ & $30<(\mathrm{x}) \leq 35$ & 4,5 \\
\hline $90<($ TATO $) \leq 105$ & $25<(\mathrm{x}) \leq 30$ & 4 \\
\hline $75<($ TATO $) \leq 90$ & $20<(\mathrm{x}) \leq 25$ & 3,5 \\
\hline $60<($ TATO $) \leq 75$ & $15<(\mathrm{x}) \leq 20$ & 3 \\
\hline $40<($ TATO $) \leq 60$ & $10<(\mathrm{x}) \leq 15$ & 2,4 \\
\hline $20<($ TATO $) \leq 40$ & $6<(\mathrm{x}) \leq 10$ & 1,8 \\
\hline$($ TATO $) \leq 20$ & $3<(\mathrm{x}) \leq 6$ & 1,2 \\
\hline
\end{tabular}

8) Rasio Total Modal Sendiri terhadap Total Aset

Berikut rumus perhitungan untuk menganalisis Rasio TMS terhadap TA:

$$
\text { TMS terhadap TA }=\frac{\text { Total Modal Sendiri }}{\text { Total Aset }} \times 100 \%
$$

Berdasarkan perhitungan, maka dikonversikan angka hasil perhitungan sebagaimana tabel berikut.

Tabel 9. Daftar Skor untuk Rasio TMS terhadap TA

\begin{tabular}{|c|c|}
\hline $\begin{array}{c}\text { TMS terhadap TA } \mathbf{x}= \\
(\mathbf{\%})\end{array}$ & SKOR \\
\hline$(\mathrm{x})<0$ & 0 \\
\hline $0 \leq(\mathrm{x})<10$ & 4 \\
\hline
\end{tabular}




\begin{tabular}{|c|c|}
\hline $\begin{array}{c}\text { TMS terhadap TA } \mathbf{x}= \\
(\mathbf{\%})\end{array}$ & SKOR \\
\hline $10 \leq(\mathrm{x})<20$ & 6 \\
\hline $20 \leq(\mathrm{x})<30$ & 7,25 \\
\hline $30 \leq(\mathrm{x})<40$ & 10 \\
\hline $40 \leq(\mathrm{x})<50$ & 9 \\
\hline $50 \leq(\mathrm{x})<60$ & 8,5 \\
\hline $60 \leq(\mathrm{x})<70$ & 8 \\
\hline $70 \leq(\mathrm{x})<80$ & 7,5 \\
\hline $80 \leq(\mathrm{x})<90$ & 7 \\
\hline $90 \leq(\mathrm{x})<100$ & 6,5 \\
\hline
\end{tabular}

Hasil seluruh perhitungan 8 indikator di atas kemudian diakumulasikan sebagaimana tabel di bawah ini.

Tabel 10. Daftar pengakumulasian indikator

\begin{tabular}{|c|c|c|c|}
\hline \multirow[b]{2}{*}{ No } & \multirow[b]{2}{*}{ Indikator } & \multicolumn{2}{|c|}{ Bobot } \\
\hline & & $\begin{array}{c}\text { Infra } \\
\text { Struktur }\end{array}$ & $\begin{array}{l}\text { Non Infra } \\
\text { Struktur }\end{array}$ \\
\hline 1 & $\begin{array}{l}\text { Imbalan para pemegang } \\
\text { sero/saham }\end{array}$ & 15 & 20 \\
\hline 2 & Imbalan investasi & 10 & 15 \\
\hline 3 & Rasio Kas & 3 & 5 \\
\hline 4 & Rasio Lancar & 4 & 5 \\
\hline 5 & $\begin{array}{l}\text { Collection } \\
\text { Periods/Perputaran } \\
\text { Piutang (CP) } \\
\end{array}$ & 4 & 5 \\
\hline 6 & $\begin{array}{l}\text { Rasio Perputaran } \\
\text { Persediaan (PP) }\end{array}$ & 4 & 5 \\
\hline 7 & $\begin{array}{l}\text { Total Asset Turn-Over } \\
\text { (TATO) }\end{array}$ & 4 & 5 \\
\hline 8 & Rasio TMS terhadap TA & 6 & 10 \\
\hline & Akumulasi & 50 & 70 \\
\hline
\end{tabular}

Jika akumulasi bobot diketahui, dilanjutkan dengan perhitungan total skor (TS). Total skor berfungsi guna menentukan kategori kesehatan pada penilaian tingkat kesehatan BUMN, berikut rumusnya.

$$
\text { Total Skor }(\mathrm{TS})=\frac{\text { Akumulasi Bobot Indikator }}{\text { Total Bobot Standar }} \times 100
$$

Total skor yang telah diketahui selanjutnya diklasifikasikan sesuai pengelompokkan pada tabel di bawah ini. 
Tabel 11. Kategori Penilaian Berdasarkan SK Menteri No.KEP-100/MBU/2002

\begin{tabular}{|c|c|c|}
\hline \multirow{4}{*}{ "SEHAT" } & $\underline{\mathrm{AAA}}$ & $(\mathrm{TS})>95$ \\
\cline { 2 - 3 } & $\underline{\mathrm{AA}}$ & $80<(\mathrm{TS}) \leq 95$ \\
\cline { 2 - 3 } & $\underline{\mathrm{A}}$ & $65<(\mathrm{TS}) \leq 80$ \\
\hline \multirow{3}{*}{$\begin{array}{c}\text { KEURANG } \\
\text { SEHAT" }\end{array}$} & $\underline{\mathrm{BBB}}$ & $50<(\mathrm{TS}) \leq 65$ \\
\cline { 2 - 3 } & $\underline{\mathrm{BB}}$ & $40<(\mathrm{TS}) \leq 50$ \\
\hline \multirow{3}{*}{$\begin{array}{c}\text { "TIDAK } \\
\text { SEHAT" }\end{array}$} & $\underline{\mathrm{CCC}}$ & $30<(\mathrm{TS}) \leq 40$ \\
\cline { 2 - 3 } & $\underline{\mathrm{CC}}$ & $20<(\mathrm{TS}) \leq 30$ \\
\cline { 2 - 3 } & $\underline{\mathrm{C}}$ & $10<(\mathrm{TS}) \leq 20$ \\
\hline
\end{tabular}

Pada tabel 11, kita dapat mengetahui dan menyimpulkan tingkat kesehatan kinerja keuangan perusahaan BUMN dan mengidentifikasi pengaruh tiap-tiap indikator perhitungannya.

\subsection{Industri Pertahanan (Indhan)}

Indonesia sebagai negara hukum telah menerangkan secara detail tentang industri pertahanan di Indonesia dalam UURI No. 16 Tahun 2012 tentang Industri Pertahanan.

Dalam pasal 1 ayat 1 dijelaskan "Industri Pertahanan adalah industri nasional yang terdiri atas badan usaha milik negara dan badan usaba milik swasta baik secara sendiri maupun berkelompok yang ditetapkan oleb pemerintah untuk sebagian atau selurubnya menghasilkan alat peralatan pertahanan dan keamanan, jasa pemelibaraan untuk memenubi kepentingan strategis di bidang pertabanan dan keamanan yang berlokasi di wilayah Negara Kesatuan Republik. Indonesia”.

\subsection{Profil PT Dahana (Persero)}

PT Dahana (Persero) ialah perusahaan BUMN yang bergerak di bidang industri bahan dan alat peledak yang mulai berdiri sejak tahun 1966. Berawal dari pabrik dinamit hingga berkembang sampai hari ini merambah ke bidang militer dan komersial publik.

Beberapa bidang usaha PT Dahana (Persero) ialah sebagai berikut.

1) Pengeboran dan Peledakan (Drilling and Blasting)

2) Produksi Bahan Peledak (Explosives Manufacturing)

3) Jasa-Jasa Terkait Bahan Peledak (Explosives Related Services)

4) Bahan Peledak Pertahanan (Defense Related)

\subsection{Profil PT Industri Telekomunikasi Indonesia (Persero)}

PT Industri Telekomunikasi Indonesia (Persero) atau sering dikenal sebagai PT INTI merupakan perusahaan BUMN yang bergerak di bidang industri telekomunikasi, elektronika, dan bidang sejenis baik untuk komersial publik maupun pertahanan negeri.

Perusahaan ini secara rinci memiliki spesialiasasi di bidang diantaranya sebagai berikut.

1) Produksi alat/perangkat bidang telekomunikasi, informatika, elektronika termasuk piranti lunak yang berkaitan, juga untuk diaplikasikan dalam bidang energi, perhubungan, infrastruktur, pertahanan keamanan, dan lain-lain.

2) Perdagangan alat/perangkat sebagaimana disebutkan sebelumnya baik hasil produk sendiri maupun hasil produk pihak lain, juga melakukan pemasokan di bidang telematika, perhubungan, energi dan kelistrikan, serta melakukan perdagangan umum termasuk ekspor impor, distribusi dan keagenan.

3) Penyediaan jasa yang berkaitan dengan produksi dan perdagangan di atas, termasuk jasa 
desain dan rekayasa, perakitan, instalasi dan tes, pemborongan, konstruksi, pengangkutan, pemeliharaan, purna jual, managed service, penelitian dan pengembangan, konsultasi, manajemen proyek, pelatihan, dan sebagainya.

\subsection{Profil PT Pindad (Persero)}

PT Pindad (Persero) merupakan perusahaan BUMN yang bergerak khusus di bidang industri pertahanan khususnya untuk memasok kebutuhan militer Negara Kesatuan Republik Indonesia (NKRI). PT Pindad merupakan industri militer/pertahanan pertama di Indonesia yang mulai berdiri di era penjajahan Belanda hingga terus berkembang dan bermetamorfosis menjadi PT Pindad (Persero) hari ini.

Berikut beberapa bidang usaha PT Pindad (Persero).

1) Manufaktur
a. Weapon and Munition
b. Special Vebicle
c. Militer dan Komersial
d. Konversi Energi
e. Industrial Machinery \& Equipment
f. Mechanical, electrikal, optical, dan optoelektronic

2) Jasa

a. Industrial Systems Engineering

b. Maintenance and Repair of Products/Equipments

c. Pengujian mutu dan kalibrasi (Quality Testing and Calibration)

d. Konstruksi (Construction)

e. Permesinan (Machinery)

f. Perlakuan Panas dan Permukaan (Heat and Surface Treatment)

g. Peledakan (Explosion)

3) Perdagangan

Pemasaran, penjualan, dan distribusi produk dan jasa perusahaan termasuk produksi pihak lain, baik di dalam maupun luar negeri.

\subsection{Penelitian yang Relevan}

1) Penelitian yang dilakukan oleh Siti Fairuz Azzahra dalam tugas akhir berjudul "Analisis Kinerja Kenangan Pada Perusahaan BUMN Sektor Pertambangan Yang Terdaftar di Bursa Efek Indonesia Periode 2012-2016”.

2) Penelitian sarjana yang dilakukan oleh Fandy G.S. pada skripsinya yang berjudul "Analisis Kinerja Kenangan Perusahaan BUMN Bidang Konstruksi Yang Terdaftar di Bursa Efek. Indonesia Periode 2010-2013".

3) Penelitian sarjana yang dilakukan oleh Erni Kurnia Lestari dalam skripsi berjudul "Analisis Penilaian Tingkat Keseharan BUMN Pada PT Taspen Tabun 2012-2014".

4) Penelitian yang dilakukan oleh Shella A.M. pada jurnal berjudul "Analisis Penilaian Tingkat Kesehatan Badan Usaha Milik. Negara (BUMN) Jasa Kenangan Bidang Usaha Perasuransian dan Jasa Penjaminan Periode 2014-2015".

5) Penelitian yang dilakukan oleh Putu Cahya Baskara dan Henny Rahyuda pada jurnal yang berjudul "Penilaian Tingkat Kesehatan Kenangan PT Pegadaian (Persero) Bedasarkan Keputusan Menteri BUMN No: (KEP-100/MBU/2002)".

\section{Metode Penelitian}

Penelitian ini didesain dengan desain penelitian evaluasi (evaluation researcb). Penelitian ini menilai sejauh mana tingkat kesehatan kinerja keuangan perusahaan BUMN bidang industri pertahanan (Indhan) Indonesia periode 2015-2019 berdasarkan tolok ukur Surat Keputusan (SK) 
Menteri BUMN No. (KEP-100/MBU/2002).

Adapun data pada penelitian ini ialah berjenis data kuantitatif dengan teknik pengambilan data menggunakan teknik dokumentasi bersumber dari laporan keuangan tahunan konsolidasi perusahaan BUMN teraudit Akuntan Publik periode 2015-2019 yang dipublikasi pada website sebagai berikut. (Catatan: Data diakses pada awal bulan Juli 2020)

Tabel 12. Sumber Data Penelitian

\begin{tabular}{|c|l|l|}
\hline No & \multicolumn{1}{|c|}{ Perusahaan } & \multicolumn{1}{c|}{ Website Resmi } \\
\hline 1 & PT Dahana (Persero) & www.dahana.id \\
\hline 2 & $\begin{array}{l}\text { PT Indusrri Telekomunikasi } \\
\text { Indonesia (Persero) }\end{array}$ & www.inti.co.id \\
\hline 3 & PT Pindad (Persero) & www.pindad.com \\
\hline
\end{tabular}

Sampel penelitian terdiri atas tiga perusahaan yang terpilih dari total sejumlah sembilan perusahaan sejenis atas seleksi yang penulis tetapkan pada penelitian. Sampel penelitian terdiri dari: 1. PT Dahana (Persero); 2. PT Industri Telekomunikasi Indonesia (Persero); dan 3. PT Pindad (Persero).

Variabel penelitian ini penulis merupakan variabel mandiri. Kemudian untuk teknik analisis data, penulis menggunakan teknik analisa data bertolok-ukur Surat Keputusan (SK) Menteri BUMN No.(KEP-100/MBU/2002). Guna melengkapi gambaran bagaimana penelitian ini dilakukan, berikut paradigma berpikir pada penelitian.

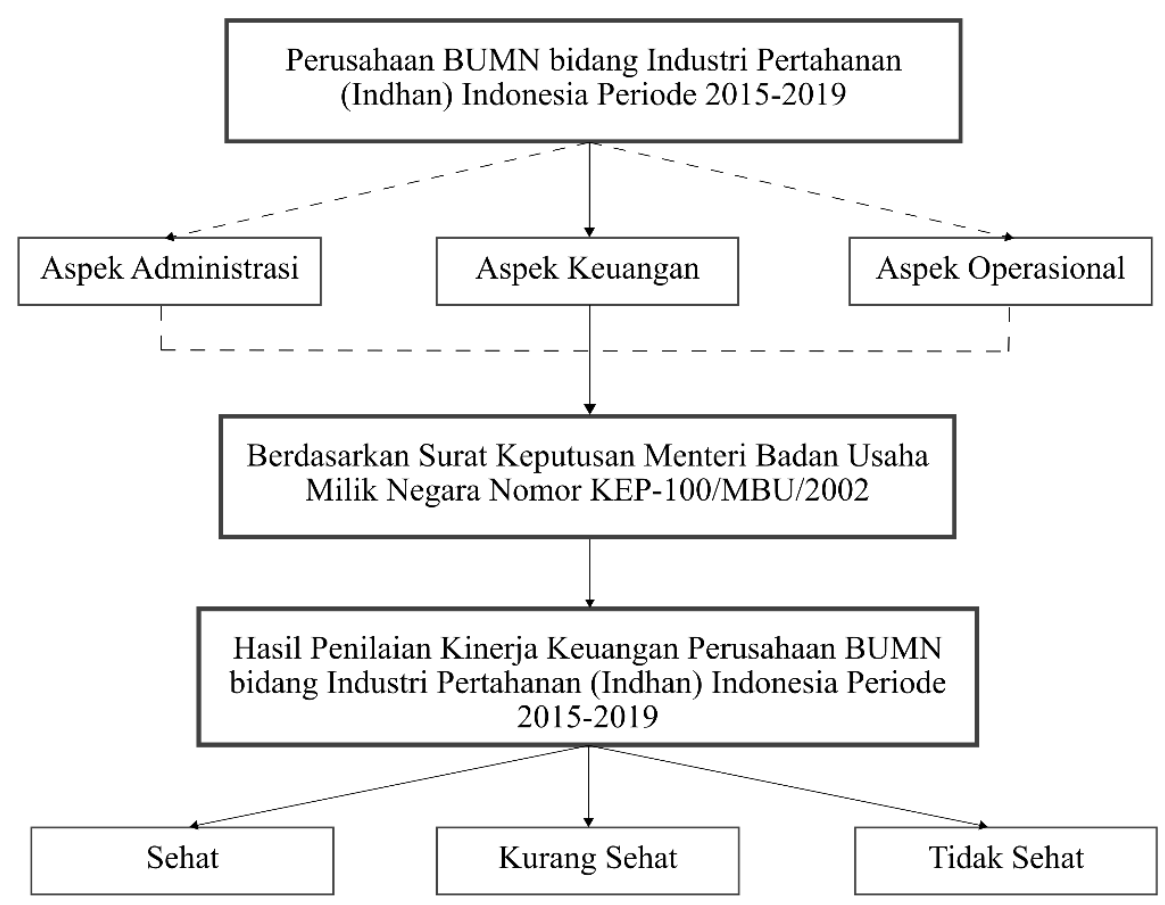

Gambar 1. Kerangka Berpikir

Keterangan:

$\longrightarrow=$ Hal yang dibahas pada penelitian.

-..-. = Hal yang tidak dibahas pada penelitian. 


\section{Hasil dan Pembahasan} berikut.

Berdasarkan hasil perhitungan yang telah dilakukan, diperoleh hasil penelitian sebagai

1) Penilaian Tingkat Kesehatan Kinerja Keuangan PT Dahana (Persero)

a. Return on Equity (ROE)

Tabel 13. ROE PT Dahana (Persero) periode 2015-2019 (Ditampilkan dalam mata uang Rp., kecuali ditampilkan secara khusus)

\begin{tabular}{|c|c|c|c|c|}
\hline Tahun & $\begin{array}{c}\text { Laba Setelah } \\
\text { Pajak }\end{array}$ & Modal Sendiri & ROE (\%) & Bobot \\
\hline 2015 & $78.639 .959 .366,00$ & $512.729 .614 .670,00$ & 15,34 & 20 \\
\hline 2016 & $82.099 .097 .851,00$ & $596.590 .443 .993,00$ & 13,76 & 18 \\
\hline 2017 & $125.257 .697 .441,00$ & $675.853 .954 .100,00$ & 18,53 & 20 \\
\hline 2018 & $133.964 .604 .925,00$ & $807.558 .917 .860,00$ & 16,59 & 20 \\
\hline 2019 & $74.098 .061 .419,00$ & $927.710 .571 .510,00$ & 7,99 & 12 \\
\hline
\end{tabular}

b. Pengembalian investasi (ROI)

Tabel 14. ROI PT Dahana (Persero) periode 2015-2019 (Ditampilkan dalam mata uang Rp., kecuali ditampilkan secara khusus)

\begin{tabular}{|c|c|c|c|c|}
\hline Tahun & $\begin{array}{c}\text { EBIT + } \\
\text { Penyusutan }\end{array}$ & Capital Employed & $\begin{array}{c}\text { ROI } \\
\mathbf{( \% )}\end{array}$ & Bobot \\
\hline 2015 & $138.524 .971 .907,00$ & $1.305 .839 .946 .240,00$ & 10,61 & 9 \\
\hline 2016 & $134.153 .443 .838,00$ & $1.254 .309 .725 .425,00$ & 10,70 & 9 \\
\hline 2017 & $178.493 .452 .967,00$ & $1.492 .078 .617 .157,00$ & 11,96 & 9 \\
\hline 2018 & $193.658 .441 .884,00$ & $1.795 .258 .133 .499,00$ & 10,79 & 9 \\
\hline 2019 & $123.700 .053 .159,00$ & $1.857 .671 .269 .734,00$ & 6,66 & 5 \\
\hline
\end{tabular}

c. Rasio Kas

Tabel 15. Rasio Kas PT Dahana (Persero) periode 2015-2019 (Ditampilkan dalam mata uang Rp., kecuali ditampilkan secara khusus)

\begin{tabular}{|c|c|c|c|c|}
\hline Tahun & K+B+SBJK & $\begin{array}{c}\text { Current } \\
\text { Liabilities }\end{array}$ & $\begin{array}{c}\text { CaR } \\
\mathbf{( \% )}\end{array}$ & Bobot \\
\hline 2015 & $107.720 .032 .546,00$ & $686.894 .277 .719,00$ & 15,68 & 3 \\
\hline 2016 & $111.738 .094 .168,00$ & $565.745 .567 .295,00$ & 19,75 & 3 \\
\hline 2017 & $192.001 .367 .786,00$ & $685.142 .551 .678,00$ & 28,02 & 4 \\
\hline 2018 & $206.206 .165 .349,00$ & $847.932 .524 .710,00$ & 24,32 & 3 \\
\hline 2019 & $275.461 .055 .405,00$ & $789.043 .827 .202,00$ & 34,91 & 4 \\
\hline
\end{tabular}

d. Rasio Lancar

Tabel 16. Rasio Lancar PT Dahana (Persero) periode 2015-2019 (Ditampilkan dalam mata uang Rp., kecuali ditampilkan secara khusus)

\begin{tabular}{|c|c|c|c|c|}
\hline Tahun & Current Asset & $\begin{array}{c}\text { Current } \\
\text { Liabilities }\end{array}$ & $\begin{array}{c}\text { CuR } \\
(\mathbf{\%})\end{array}$ & Bobot \\
\hline 2015 & $808.017 .462 .918,00$ & $686.894 .277 .719,00$ & 117,63 & 4 \\
\hline 2016 & $753.525 .443 .060,00$ & $565.745 .567 .295,00$ & 133,19 & 5 \\
\hline 2017 & $997.178 .378 .058,00$ & $685.142 .551 .678,00$ & 145,54 & 5 \\
\hline
\end{tabular}




\begin{tabular}{|c|c|c|c|c|}
\hline Tahun & Current Asset & $\begin{array}{c}\text { Current } \\
\text { Liabilities }\end{array}$ & $\begin{array}{c}\text { CuR } \\
\mathbf{( \% )}\end{array}$ & Bobot \\
\hline 2018 & $1.246 .662 .589 .337,00$ & $847.932 .524 .710,00$ & 147,02 & 5 \\
\hline 2019 & $1.278 .645 .096 .320,00$ & $789.043 .827 .202,00$ & 162,05 & 5 \\
\hline
\end{tabular}

e. Collection Periods (CP)

Tabel 17. Rasio CP PT Dahana (Persero) periode 2015-2019 (Ditampilkan dalam mata uang Rp., kecuali ditampilkan secara khusus)

\begin{tabular}{|c|c|c|c|c|c|}
\hline Tahun & $\begin{array}{c}\text { Total Piutang } \\
\text { Usaha }\end{array}$ & Pendapatan Usaha & CP & Perbaikan & $\begin{array}{c}\text { Bobot } \\
\text { Akhir }\end{array}$ \\
\hline 2015 & $288.959 .541 .675,00$ & $1.376 .172 .945 .262,00$ & 77 Hari & 5 Hari & 4,5 \\
\hline 2016 & $232.794 .841 .087,00$ & $1.371 .655 .722 .352,00$ & 62 Hari & 15 Hari & 4,5 \\
\hline 2017 & $321.142 .986 .160,00$ & $1.550 .434 .267 .305,00$ & 76 Hari & -14 Hari & 4,5 \\
\hline 2018 & $408.424 .889 .761,00$ & $1.982 .661 .606 .068,00$ & 75 Hari & 0 Hari & 4,5 \\
\hline 2019 & $380.288 .363 .073,00$ & $1.989 .400 .301 .110,00$ & 70 Hari & 5 Hari & 4,5 \\
\hline
\end{tabular}

f. Perputaran Persediaan (PP)

Tabel 18. Rasio Perputaran Persediaan PT Dahana (Persero) periode 2015-2019 (Ditampilkan dalam mata uang Rp., kecuali ditampilkan secara khusus)

\begin{tabular}{|c|c|c|c|c|c|}
\hline Tahun & Total Persediaan & Pendapatan Usaha & PP & Perbaikan & $\begin{array}{c}\text { Bobot } \\
\text { Akhir }\end{array}$ \\
\hline 2015 & $189.427 .991 .993,00$ & $1.376 .172 .945 .262,00$ & 50 Hari & 4 Hari & 5 \\
\hline 2016 & $185.951 .328 .664,00$ & $1.371 .655 .722 .352,00$ & 49 Hari & 1 Hari & 5 \\
\hline 2017 & $205.178 .092 .715,00$ & $1.550 .434 .267 .305,00$ & 48 Hari & 1 Hari & 5 \\
\hline 2018 & $347.078 .554 .197,00$ & $1.982 .661 .606 .068,00$ & 64 Hari & -16 Hari & 4,5 \\
\hline 2019 & $337.373 .205 .427,00$ & $1.989 .400 .301 .110,00$ & 62 Hari & 2 Hari & 4,5 \\
\hline
\end{tabular}

g. Perputaran Total Aset (TATO)

Tabel 19. TATO PT Dahana (Persero) periode 2015-2019 (Ditampilkan dalam mata uang Rp., kecuali ditampilkan secara khusus)

\begin{tabular}{|c|c|c|c|c|c|}
\hline Tahun & Total Pendapatan & Capital Employed & $\begin{array}{c}\text { TATO } \\
\mathbf{( \% )}\end{array}$ & $\begin{array}{c}\text { Perbaikan } \\
\mathbf{( \% )}\end{array}$ & $\begin{array}{c}\text { Bobot } \\
\text { Akhir }\end{array}$ \\
\hline 2015 & $1.372 .223 .996 .108,00$ & $1.305 .839 .946 .240,00$ & 105,08 & 7,82 & 4,5 \\
\hline 2016 & $1.373 .941 .011 .851,00$ & $1.254 .309 .725 .425,00$ & 109,54 & 4,45 & 4,5 \\
\hline 2017 & $1.576 .319 .400 .357,00$ & $1.492 .078 .617 .157,00$ & 105,65 & $-3,89$ & 4,5 \\
\hline 2018 & $2.016 .537 .616 .657,00$ & $1.795 .258 .133 .499,00$ & 112,33 & 6,68 & 4,5 \\
\hline 2019 & $2.009 .175 .555 .643,00$ & $1.857 .671 .269 .734,00$ & 108,16 & $-4,17$ & 4,5 \\
\hline
\end{tabular}

b. Rasio TMS terhadap TA

Tabel 20. Rasio TMS terhadap TA PT Dahana (Persero) periode 2015-2019 (Ditampilkan dalam mata uang Rp., kecuali ditampilkan secara khusus)

\begin{tabular}{|c|c|c|c|c|}
\hline Tahun & $\begin{array}{c}\text { Total Modal } \\
\text { Sendiri }\end{array}$ & Total Aset & $\begin{array}{c}\text { TMStTA } \\
\mathbf{( \% )}\end{array}$ & Bobot \\
\hline 2015 & $534.839 .122 .838,00$ & $1.238 .878 .130 .342,00$ & 43,17 & 9 \\
\hline
\end{tabular}




\begin{tabular}{|c|c|c|c|c|}
\hline Tahun & $\begin{array}{c}\text { Total Modal } \\
\text { Sendiri }\end{array}$ & Total Aset & $\begin{array}{c}\text { TMStTA } \\
(\mathbf{\%})\end{array}$ & Bobot \\
\hline 2016 & $617.055 .636 .345,00$ & $1.192 .675 .819 .926,00$ & 51,74 & 8,5 \\
\hline 2017 & $696.146 .132 .834,00$ & $1.387 .113 .098 .450,00$ & 50,19 & 8,5 \\
\hline 2018 & $827.884 .664 .617,00$ & $1.681 .619 .275 .331,00$ & 49,23 & 9 \\
\hline 2019 & $947.116 .638 .869,00$ & $1.802 .979 .275 .674,00$ & 52,53 & 8,5 \\
\hline
\end{tabular}

i. Hasil Penelitian Tingkat Kesehatan Kinerja Keuangan PT Dahana (Persero)

Tabel 21. Hasil Penelitian PT Dahana (Persero) periode 2015-2019 (Ditampilkan dalam mata uang Rp., kecuali ditampilkan secara khusus)

\begin{tabular}{|c|c|c|c|c|c|c|}
\hline \multirow{2}{*}{ NO } & \multirow{2}{*}{ INDIKATOR } & 2015 & 2016 & 2017 & 2018 & 2019 \\
\hline & & BOBOT & $\overline{\text { BOBOT }}$ & BOBOT & $\overline{\text { BOBOT }}$ & $\overline{\text { BOBOT }}$ \\
\hline 1 & ROE & 20 & 18 & 20 & 20 & 12 \\
\hline 2 & ROI & 9 & 9 & 9 & 9 & 5 \\
\hline 3 & Rasio Kas & 3 & 3 & 4 & 3 & 4 \\
\hline 4 & Rasio Lancar & 4 & 5 & 5 & 5 & 5 \\
\hline 5 & Collection Periods (CP) & 4,5 & 4,5 & 4,5 & 4,5 & 4,5 \\
\hline 6 & Perputaran Persediaan (PP) & 5 & 5 & 5 & 4,5 & 4,5 \\
\hline 7 & $\begin{array}{l}\text { Total Asset Turn Over } \\
\text { (TATO) }\end{array}$ & 4,5 & 4,5 & 4,5 & 4,5 & 4,5 \\
\hline 8 & Rasio TMS terhadap TA & 9 & 8,5 & 8,5 & 9 & 8,5 \\
\hline & AKUMULASI BOBOT & 59 & 57,5 & 60,5 & 59,5 & 48 \\
\hline & TOTAL SKOR & 84,29 & 82,14 & 86,43 & 85,00 & 68,57 \\
\hline & TINGKAT KESEHATAN & SEHAT & SEHAT & SEHAT & SEHAT & SEHAT \\
\hline & KATEGORI & AA & AA & AA & AA & $\mathbf{A}$ \\
\hline
\end{tabular}

PT Dahana (Persero) memperoleh tingkat kesehatan keuangan yang "Sehat" dengan kategori "AA" pada tahun 2015 hingga 2018 dan kategori "A" pada tahun 2019. Dalam waktu lima tahun, PT Dahana (Persero) meraih akumulasi bobot yang fluktuatif. Pada tahun 2015, PT Dahana memperoleh nilai kumulatif bobot 59 dengan total skor 84,29. Capaian kumulatif bobot di tahun 2015 ternyata tidak kembali dicapai perusahaan, hal ini dikarenakan pada tahun 2016 PT Dahana (Persero) memperoleh akumulasi bobot sebesar 57,5 dengan total skor 84,29. Perbaikan kinerja perusahaan pada aspek keuangan berbuah hasil di tahun 2017, perusahaan berhasil meningkatkan kinerja keuangan hingga memperoleh akumulasi bobot sebesar 60,5 dengan total skor 86,43, capaian ini merupakan prestasi perusahaan tertinggi selama kurun waktu tahun 2015-2019. Beralih ke tahun 2018, kinerja PT Dahana (Persero) kembali mengalami penurunan setelah sebelumnya di tahun 2017 meningkat, tahun ini perusahaan memperoleh akumulasi bobot sebesar 59,5 dengan total skor 85,00.

Fluktuasi perusahaan yang berlangsung dalam empat tahun di atas tidak menjadikan status perusahaan berubah dari tingkat "Sehat" kategori "AA", namun hal yang drastis terjadi di tahun 2019, perusahaan mengalami penurunan akumulasi bobot yang cukup besar dibanding penurunan pada tahun-tahun sebelumnya, yakni sebesar 11,5. Hal ini menyebabkan akumulasi bobot PT Dahana (Persero) di tahun 2019 menjadi 48 dengan total skor sebesar 68,57. Penurunan di tahun 2019 merupakan 
capaian terendah perusahaan dalam kurun waktu 2015-2019.

2) Penilaian Tingkat Kesehatan Kinerja Keuangan PT Industri Telekomunikasi Indonesia (Persero)

a. Imbalan pemegang sabam/Return on Equity (ROE)

Tabel 22. ROE PT Industri Telekomunikasi Indonesia (Persero) periode 2015-2019

(Ditampilkan dalam mata uang Rp., kecuali ditampilkan secara khusus)

\begin{tabular}{|c|c|c|c|c|}
\hline Tahun & $\begin{array}{c}\text { Laba Setelah } \\
\text { Pajak }\end{array}$ & Modal Sendiri & $\begin{array}{c}\text { ROE } \\
\mathbf{( \% )}\end{array}$ & Bobot \\
\hline 2015 & $(283.660 .714 .578,00)$ & $807.967 .061 .336,00$ & $-35,11$ & 0 \\
\hline 2016 & $(316.198 .525 .948,00)$ & $506.939 .583 .477,00$ & $-62,37$ & 0 \\
\hline 2017 & $6.610 .955 .679,00$ & $207.671 .616 .864,00$ & 3,18 & 5,5 \\
\hline 2018 & $462.656 .155,00$ & $221.105 .266 .009,00$ & 0,21 & 2 \\
\hline 2019 & $(434.765 .473 .171,00)$ & $166.128 .232 .863,00$ & $-261,70$ & 0 \\
\hline
\end{tabular}

b. Pengembalian investasi (ROI)

Tabel 23. ROI PT Industri Telekomunikasi Indonesia (Persero) periode 2015-2019 (Ditampilkan dalam mata uang Rp., kecuali ditampilkan secara khusus)

\begin{tabular}{|c|c|c|c|c|}
\hline Tahun & $\begin{array}{c}\text { EBIT + } \\
\text { Penyusutan }\end{array}$ & Capital Employed & $\begin{array}{c}\text { ROI } \\
\mathbf{( \% )}\end{array}$ & Bobot \\
\hline 2015 & $(252.293 .792 .738,00)$ & $1.869 .763 .721 .691,00$ & $-13,49$ & 1 \\
\hline 2016 & $(296.182 .208 .702,00)$ & $1.366 .832 .637 .096,00$ & $-21,67$ & 1 \\
\hline 2017 & $21.853 .050 .875,00$ & $2.026 .983 .628 .140,00$ & 1,08 & 3 \\
\hline 2018 & $17.142 .860 .613,00$ & $1.829 .674 .439 .106,00$ & 0,94 & 2 \\
\hline 2019 & $(452.903 .232 .447,00)$ & $1.393 .342 .534 .993,00$ & $-32,50$ & 1 \\
\hline
\end{tabular}

c. Rasio Kas

Tabel 24. Rasio Kas PT Industri Telekomunikasi Indonesia (Persero) periode 2015-2019

(Ditampilkan dalam mata uang Rp., kecuali ditampilkan secara khusus)

\begin{tabular}{|c|r|r|c|c|}
\hline Tahun & K+B+SBJK & Current Liabilities & $\begin{array}{c}\text { CaR } \\
\mathbf{( \% )}\end{array}$ & Bobot \\
\hline 2015 & $181.868 .354 .936,00$ & $1.244 .939 .256 .409,00$ & 14,61 & 2 \\
\hline 2016 & $56.204 .802 .020,00$ & $1.043 .514 .565 .791,00$ & 5,39 & 1 \\
\hline 2017 & $442.425 .005 .630,00$ & $1.704 .424 .565 .445,00$ & 25,96 & 4 \\
\hline 2018 & $51.524 .428 .776,00$ & $1.485 .561 .816 .863,00$ & 3,47 & 0 \\
\hline 2019 & $74.710 .929 .240,00$ & $818.105 .452 .060,00$ & 9,13 & 1 \\
\hline
\end{tabular}

d. Rasio Lancar

Tabel 25. Rasio Lancar PT Industri Telekomunikasi Indonesia (Persero) periode 2015-2019 (Ditampilkan dalam mata uang Rp., kecuali ditampilkan secara khusus)

\begin{tabular}{|c|r|c|c|c|}
\hline Tahun & \multicolumn{1}{|c|}{ Current Asset } & Current Liabilities & $\begin{array}{c}\text { CuR } \\
\mathbf{( \% )}\end{array}$ & Bobot \\
\hline 2015 & $976.330 .474 .938,00$ & $1.244 .939 .256 .409,00$ & 78,42 & 0 \\
\hline 2016 & $478.709 .865 .361,00$ & $1.043 .514 .565 .791,00$ & 45,87 & 0 \\
\hline 2017 & $1.158 .602 .638 .938,00$ & $1.704 .424 .565 .445,00$ & 67,98 & 0 \\
\hline 2018 & $976.779 .557 .286,00$ & $1.485 .561 .816 .863,00$ & 65,75 & 0 \\
\hline
\end{tabular}




\begin{tabular}{|c|c|c|c|c|}
\hline Tahun & Current Asset & Current Liabilities & $\begin{array}{c}\text { CuR } \\
\mathbf{( \% )}\end{array}$ & Bobot \\
\hline 2019 & $481.814 .021 .090,00$ & $818.105 .452 .060,00$ & 58,89 & 0 \\
\hline
\end{tabular}

e. Collection Periods (CP)

Tabel 26. Rasio Collection Periods (CP) PT Industri Telekomunikasi Indonesia (Persero) periode 2015-2019 (Ditampilkan dalam mata uang Rp., kecuali ditampilkan secara khusus)

\begin{tabular}{|c|c|c|c|c|c|}
\hline Tahun & $\begin{array}{c}\text { Total Piutang } \\
\text { Usaha }\end{array}$ & Pendapatan Usaha & CP & Perbaikan & $\begin{array}{c}\text { Bobot } \\
\text { Akhir }\end{array}$ \\
\hline 2015 & $106.515 .443 .699,00$ & $420.991 .676 .514,00$ & 92 Hari & -70 Hari & 4 \\
\hline 2016 & $60.211 .880 .470,00$ & $681.078 .397 .077,00$ & 32 Hari & 60 Hari & 5 \\
\hline 2017 & $464.307 .428 .131,00$ & $1.308 .680 .036 .891,00$ & $\begin{array}{c}129 \\
\text { Hari }\end{array}$ & -97 Hari & 3,5 \\
\hline 2018 & $566.390 .818 .877,00$ & $847.756 .334 .888,00$ & $\begin{array}{c}244 \\
\text { Hari }\end{array}$ & -114 Hari & 1,2 \\
\hline 2019 & $75.933 .926 .213,00$ & $395.377 .565 .599,00$ & 70 Hari & 174 Hari & 5 \\
\hline
\end{tabular}

f. Perputaran Persediaan (PP)

Tabel 27. Rasio Perputaran Persediaan (PP) PT Industri Telekomunikasi Indonesia (Persero) periode 2015-2019 (Ditampilkan dalam mata uang Rp., kecuali ditampilkan secara khusus)

\begin{tabular}{|c|r|r|c|c|c|}
\hline Tahun & Total Persediaan & Pendapatan Usaha & PP & Perbaikan & $\begin{array}{c}\text { Bobot } \\
\text { Akhir }\end{array}$ \\
\hline 2015 & $200.314 .963 .346,00$ & $420.991 .676 .514,00$ & $\begin{array}{c}174 \\
\text { Hari }\end{array}$ & -43 Hari & 3 \\
\hline 2016 & $94.005 .499 .387,00$ & $681.078 .397 .077,00$ & 50 Hari & 123 Hari & 5 \\
\hline 2017 & $174.542 .760 .355,00$ & $1.308 .680 .036 .891,00$ & 49 Hari & 2 Hari & 5 \\
\hline 2018 & $267.223 .175 .674,00$ & $847.756 .334 .888,00$ & $\begin{array}{c}115 \\
\text { Hari }\end{array}$ & -66 Hari & 4 \\
\hline 2019 & $252.365 .505 .375,00$ & $395.377 .565 .599,00$ & $\begin{array}{c}233 \\
\text { Hari }\end{array}$ & -118 Hari & 1,8 \\
\hline
\end{tabular}

g. Perputaran Total Aset (TATO)

Tabel 28. TATO PT Industri Telekomunikasi Indonesia (Persero) periode 2015-2019

(Ditampilkan dalam mata uang Rp., kecuali ditampilkan secara khusus)

\begin{tabular}{|c|c|c|c|c|c|}
\hline Tahun & Total Pendapatan & Capital Employed & $\begin{array}{c}\text { TATO } \\
\mathbf{( \% )}\end{array}$ & $\begin{array}{c}\text { Perbaikan } \\
\mathbf{( \% )}\end{array}$ & $\begin{array}{c}\text { Bobot } \\
\text { Akhir }\end{array}$ \\
\hline 2015 & $476.926 .506 .586,00$ & $1.869 .763 .721 .691,00$ & 25,51 & $-26,47$ & 2,5 \\
\hline 2016 & $707.537 .101 .366,00$ & $1.366 .832 .637 .096,00$ & 51,76 & 26,26 & 5 \\
\hline 2017 & $1.339 .999 .652 .371,00$ & $2.026 .983 .628 .140,00$ & 66,11 & 14,34 & 4 \\
\hline 2018 & $863.718 .621 .472,00$ & $1.829 .674 .439 .106,00$ & 47,21 & $-18,90$ & 2,5 \\
\hline 2019 & $409.096 .350 .815,00$ & $1.393 .342 .534 .993,00$ & 29,36 & $-17,85$ & 2,5 \\
\hline
\end{tabular}

h. Rasio TMS terhadap TA 
Tabel 29. Rasio TMS terhadapTA PT Industri Telekomunikasi Indonesia (Persero) periode 2015-2019 (Ditampilkan dalam mata uang Rp., kecuali ditampilkan secara khusus)

\begin{tabular}{|c|c|c|c|c|}
\hline Tahun & $\begin{array}{c}\text { Total Modal } \\
\text { Sendiri }\end{array}$ & Total Aset & $\begin{array}{c}\text { TMStTA } \\
\mathbf{( \% )}\end{array}$ & Bobot \\
\hline 2015 & $1.150 .343 .724 .912,00$ & $2.495 .801 .099 .845,00$ & 46,09 & 9 \\
\hline 2016 & $1.132 .130 .032 .800,00$ & $2.308 .221 .612 .367,00$ & 49,05 & 9 \\
\hline 2017 & $1.149 .301 .189 .383,00$ & $2.962 .002 .244 .980,00$ & 38,80 & 10 \\
\hline 2018 & $1.154 .884 .514 .406,00$ & $2.762 .991 .031 .348,00$ & 41,80 & 9 \\
\hline 2019 & $1.191 .958 .690 .152,00$ & $2.853 .938 .465 .453,00$ & 41,77 & 9 \\
\hline
\end{tabular}

i. Hasil Penelitian Tingkat Kesehatan Kinerja Keuangan PT INTI (Persero)

Tabel 30. Hasil Penelitian PT Industri Telekomunikasi Indonesia (Persero) periode 2015-2019

(Ditampilkan dalam mata uang Rp., kecuali ditampilkan secara khusus)

\begin{tabular}{|c|l|c|c|c|c|c|}
\hline \multirow{2}{*}{ NO } & \multicolumn{1}{|c|}{ INDIKATOR } & $\mathbf{2 0 1 5}$ & $\mathbf{2 0 1 6}$ & $\mathbf{2 0 1 7}$ & $\mathbf{2 0 1 8}$ & $\mathbf{2 0 1 9}$ \\
\cline { 3 - 7 } & BOBOT & BOBOT & BOBOT & BOBOT & BOBOT \\
\hline 1 & ROE & 0 & 0 & 5,5 & 2 & 0 \\
\hline 2 & ROI & 1 & 1 & 3 & 2 & 1 \\
\hline 3 & Rasio Kas & 2 & 1 & 4 & 0 & 1 \\
\hline 4 & Rasio Lancar & 0 & 0 & 0 & 0 & 0 \\
\hline 5 & Collection Periods (CP) & 4 & 5 & 3,5 & 1,2 & 5 \\
\hline 6 & $\begin{array}{l}\text { Perputaran Persediaan } \\
\text { (PP) }\end{array}$ & 3 & 5 & 5 & 4 & 1,8 \\
\hline 7 & $\begin{array}{l}\text { Total Asset Turn Over } \\
\text { (TATO) }\end{array}$ & 2,5 & 5 & 4 & 2,5 & 2,5 \\
\hline 8 & $\begin{array}{l}\text { Rasio TMS terhadap TA } \\
\text { AKUMULASI BOBOT }\end{array}$ & 9 & 9 & 10 & 9 & 9 \\
\hline \multicolumn{2}{|c|}{ TOTAL SKOR } & 30,71 & 37,14 & 50,00 & 29,57 & 29,00 \\
\hline \multicolumn{2}{|c|}{ TINGKAT KESEHATAN } & $\begin{array}{c}\text { KURANG } \\
\text { SEHAT }\end{array}$ & $\begin{array}{c}\text { KURANG } \\
\text { SEHAT }\end{array}$ & $\begin{array}{c}\text { KURANG } \\
\text { SEHAT }\end{array}$ & $\begin{array}{c}\text { TIDAK } \\
\text { SEHAT }\end{array}$ & $\begin{array}{c}\text { TIDAK } \\
\text { SEHAT }\end{array}$ \\
\hline \multicolumn{2}{|c|}{ KEATEGORI } & B & B & BB & CCC & CCC \\
\hline
\end{tabular}

PT Industri Telekomunikasi Indonesia (Persero) atau lazim disebut PT INTI, dalam kurun waktu tahun 2015-2019 memiliki tingkat kesehatan keuangan yang fluktuatif. Perusahaan memperoleh kategori Kurang Sehat (B) pada tahun 2015 hingga 2016, kemudian meraih perbaikan pada tahun 2017 menjadi Kurang Sehat (BB). Pada tahun 2018, PT INTI mengalami penurunan tingkat kesehatan keuangan menjadi Tidak Sehat (CCC) dan terus berlangsung hingga tahun 2019 dengan tingkat kesehatan yang sama.

Jika ditinjau secara perolehan tingkat kesehatan keuangan, PT INTI perlu melakukan perbaikan manajemen guna meningkatkan kualitas kesehatan keuangan pada tingkat "Sehat".

Dalam waktu 5 tahun, perolehan tertinggi akumulasi bobot yang diraih perusahaan tercatat sebesar 35 dengan total skor 50,00 (Kurang Sehat BBB). Sedangkan perolehan tingkat kesehatan perusahaan terendah diperoleh pada tahun 2019 dengan akumulasi bobot sebesar 20,3 tingkat kesehatan Tidak Sehat (CCC). Hal ini tentunya disebabkan oleh beberapa faktor turunan dari capaian delapan indikator perusahaan yang bervariatif. 
3) Penilaian Tingkat Kesehatan Kinerja Keuangan PT Pindad (Persero) a) Imbalan pemegang saham (ROE)

Tabel 31. ROE PT Pindad (Persero) periode 2015-2019 (Ditampilkan dalam mata uang Rp., kecuali ditampilkan secara khusus)

\begin{tabular}{|c|c|c|c|c|}
\hline Tahun & $\begin{array}{c}\text { Laba Setelah } \\
\text { Pajak }\end{array}$ & Modal Sendiri & $\begin{array}{c}\text { ROE } \\
\mathbf{( \% )}\end{array}$ & Bobot \\
\hline 2015 & $4.160 .941 .076,00$ & $1.256 .145 .499 .609,00$ & 0,33 & 2 \\
\hline 2016 & $45.791 .536 .023,00$ & $1.185 .261 .394 .585,00$ & 3,86 & 5,5 \\
\hline 2017 & $92.064 .450 .299,00$ & $1.193 .768 .592 .111,00$ & 7,71 & 10 \\
\hline 2018 & $100.578 .357 .040,00$ & $1.096 .116 .605 .639,00$ & 9,18 & 14 \\
\hline 2019 & $100.531 .006 .379,00$ & $1.364 .254 .057 .076,00$ & 7,37 & 10 \\
\hline
\end{tabular}

b) Pengembalian investasi (ROI)

Tabel 32. ROI PT Pindad (Persero) periode 2015-2019 (Ditampilkan dalam mata uang Rp., kecuali ditampilkan secara khusus)

\begin{tabular}{|c|c|c|c|c|}
\hline Tahun & $\begin{array}{c}\text { EBIT + } \\
\text { Penyusutan }\end{array}$ & Capital Employed & $\begin{array}{c}\text { ROI } \\
\mathbf{( \% )}\end{array}$ & Bobot \\
\hline 2015 & $81.660 .952 .850,00$ & $4.059 .135 .370 .830,00$ & 2,01 & 3 \\
\hline 2016 & $117.068 .737 .134,00$ & $4.138 .619 .270 .698,00$ & 2,83 & 3 \\
\hline 2017 & $181.117 .521 .894,00$ & $5.943 .197 .718 .784,00$ & 3,05 & 4 \\
\hline 2018 & $212.336 .376 .835,00$ & $6.277 .160 .826 .150,00$ & 3,38 & 4 \\
\hline 2019 & $227.153 .537 .232,00$ & $6.889 .791 .694 .859,00$ & 3,30 & 4 \\
\hline
\end{tabular}

c) Rasio Kas

Tabel 33. Rasio Kas PT Pindad (Persero) periode 2015-2019 (Ditampilkan dalam mata uang Rp., kecuali ditampilkan secara khusus)

\begin{tabular}{|c|r|c|c|c|}
\hline Tahun & \multicolumn{1}{|c|}{ K+B+SBJK } & Current Liabilities & $\begin{array}{c}\text { CaR } \\
\mathbf{( \% )}\end{array}$ & Bobot \\
\hline 2015 & $1.086 .784 .047 .431,00$ & $2.286 .104 .541 .739,00$ & 47,54 & 5 \\
\hline 2016 & $902.477 .230 .632,00$ & $2.342 .295 .627 .561,00$ & 38,53 & 5 \\
\hline 2017 & $2.027 .709 .726 .189,00$ & $3.029 .645 .156 .932,00$ & 66,93 & 5 \\
\hline 2018 & $1.218 .019 .344 .678,00$ & $3.461 .802 .354 .617,00$ & 35,18 & 5 \\
\hline 2019 & $758.099 .989 .023,00$ & $4.838 .044 .115 .057,00$ & 15,67 & 3 \\
\hline
\end{tabular}

d) Rasio Lancar

Tabel 34. Rasio Lancar PT Pindad (Persero) periode 2015-2019 (Ditampilkan dalam mata uang Rp., kecuali ditampilkan secara khusus)

\begin{tabular}{|c|c|c|c|c|}
\hline Tahun & Current Asset & Current Liabilities & $\begin{array}{c}\text { CuR } \\
\mathbf{( \% )}\end{array}$ & Bobot \\
\hline 2015 & $3.497 .747 .173 .886,00$ & $2.286 .104 .541 .739,00$ & 153,00 & 5 \\
\hline 2016 & $3.579 .705 .296 .586,00$ & $2.342 .295 .627 .561,00$ & 152,83 & 5 \\
\hline 2017 & $5.350 .859 .698 .090,00$ & $3.029 .645 .156 .932,00$ & 176,62 & 5 \\
\hline 2018 & $5.607 .212 .548 .567,00$ & $3.461 .802 .354 .617,00$ & 161,97 & 5 \\
\hline
\end{tabular}




\begin{tabular}{|c|c|c|c|c|}
\hline Tahun & Current Asset & Current Liabilities & $\begin{array}{c}\text { CuR } \\
\mathbf{( \% )}\end{array}$ & Bobot \\
\hline 2019 & $5.864 .488 .052 .701,00$ & $4.838 .044 .115 .057,00$ & 121,22 & 4 \\
\hline
\end{tabular}

e) Collection Periods (CP)

Tabel 35. Rasio Collection Periods (CP) PT Pindad (Persero) periode 2015-2019 (Ditampilkan dalam mata uang Rp., kecuali ditampilkan secara khusus)

\begin{tabular}{|c|c|c|c|c|c|}
\hline Tahun & $\begin{array}{c}\text { Total Piutang } \\
\text { Usaha }\end{array}$ & Pendapatan Usaha & CP & Perbaikan & $\begin{array}{c}\text { Bobot } \\
\text { Akhir }\end{array}$ \\
\hline 2015 & $346.098 .046 .102,00$ & $1.948 .821 .017 .890,00$ & 65 Hari & 64 Hari & 5 \\
\hline 2016 & $494.014 .293 .946,00$ & $2.025 .443 .999 .847,00$ & 89 Hari & -24 Hari & 4,5 \\
\hline 2017 & $457.192 .618 .132,00$ & $2.456 .125 .855 .189,00$ & 68 Hari & 21 Hari & 4,5 \\
\hline 2018 & $372.456 .633 .871,00$ & $3.200 .897 .126 .727,00$ & 42 Hari & 25 Hari & 5 \\
\hline 2019 & $349.273 .650 .188,00$ & $3.398 .782 .965 .263,00$ & 38 Hari & 5 Hari & 5 \\
\hline
\end{tabular}

f) Perputaran Persediaan (PP)

Tabel 36. Rasio Perputaran Persediaan (PP) PT Pindad (Persero) periode 2015-2019

(Ditampilkan dalam mata uang Rp., kecuali ditampilkan secara khusus)

\begin{tabular}{|c|c|c|c|c|c|}
\hline Tahun & Total Persediaan & Pendapatan Usaha & PP & Perbaikan & $\begin{array}{c}\text { Bobot } \\
\text { Akhir }\end{array}$ \\
\hline 2015 & $977.990 .091 .449,00$ & $1.948 .821 .017 .890,00$ & 183 Hari & 96 Hari & 5 \\
\hline 2016 & $1.198 .058 .872 .162,00$ & $2.025 .443 .999 .847,00$ & 216 Hari & -33 Hari & 1,8 \\
\hline 2017 & $1.321 .704 .775 .346,00$ & $2.456 .125 .855 .189,00$ & 196 Hari & 19 Hari & 3 \\
\hline 2018 & $1.503 .814 .524 .689,00$ & $3.200 .897 .126 .727,00$ & 171 Hari & 25 Hari & 3,5 \\
\hline 2019 & $1.780 .337 .234 .343,00$ & $3.398 .782 .965 .263,00$ & 191 Hari & -20 Hari & 2,4 \\
\hline
\end{tabular}

g) Total Asset Turn Over (TATO)

Tabel 37. TATO PT Pindad (Persero) periode 2015-2019 (Ditampilkan dalam mata uang Rp., kecuali ditampilkan secara khusus)

\begin{tabular}{|c|c|c|c|c|c|}
\hline Tahun & Total Pendapatan & Capital Employed & $\begin{array}{c}\text { TATO } \\
\mathbf{( \% )}\end{array}$ & $\begin{array}{c}\text { Perbaikan } \\
\mathbf{( \% )}\end{array}$ & $\begin{array}{c}\text { Bobot } \\
\text { Akhir }\end{array}$ \\
\hline 2015 & $2.028 .031 .152 .731,00$ & $4.059 .135 .370 .830,00$ & 49,96 & $-8,22$ & 2,5 \\
\hline 2016 & $2.106 .296 .025 .443,00$ & $4.138 .619 .270 .698,00$ & 50,89 & 0,93 & 3 \\
\hline 2017 & $2.575 .199 .082 .931,00$ & $5.943 .197 .718 .784,00$ & 43,33 & $-7,56$ & 2,5 \\
\hline 2018 & $3.269 .143 .590 .118,00$ & $6.277 .160 .826 .150,00$ & 52,08 & 8,75 & 3,5 \\
\hline 2019 & $3.497 .631 .338 .487,00$ & $6.889 .791 .694 .859,00$ & 50,77 & $-1,31$ & 2,5 \\
\hline
\end{tabular}

b) Rasio TMS terhadap TA

Tabel 38. Rasio TMS terhadap TA milik PT Pindad periode 2015-2019 (Ditampilkan dalam mata uang Rp., kecuali ditampilkan secara khusus)

\begin{tabular}{|c|c|c|c|c|}
\hline Tahun & $\begin{array}{c}\text { Total Modal } \\
\text { Sendiri }\end{array}$ & Total Aset & $\begin{array}{c}\text { TMStTA } \\
\mathbf{( \% )}\end{array}$ & Bobot \\
\hline 2015 & $1.309 .185 .043 .462,00$ & $4.108 .013 .973 .607,00$ & 31,87 & 10 \\
\hline 2016 & $1.253 .389 .842 .392,00$ & $4.160 .956 .182 .482,00$ & 30,12 & 10 \\
\hline
\end{tabular}




\begin{tabular}{|c|c|c|c|c|}
\hline Tahun & $\begin{array}{c}\text { Total Modal } \\
\text { Sendiri }\end{array}$ & Total Aset & $\begin{array}{c}\text { TMStTA } \\
(\mathbf{\%})\end{array}$ & Bobot \\
\hline 2017 & $1.252 .234 .364 .452,00$ & $5.909 .599 .040 .826,00$ & 21,19 & 7,25 \\
\hline 2018 & $1.272 .242 .662 .958,00$ & $6.352 .708 .526 .429,00$ & 20,03 & 7,25 \\
\hline 2019 & $1.364 .255 .937 .334,00$ & $6.788 .713 .968 .980,00$ & 20,10 & 7,25 \\
\hline
\end{tabular}

i) Hasil Penelitian Tingkat Kesehatan Kinerja Keuangan PT Pindad (Persero)

Tabel 39. Hasil Penelitian PT Pindad (Persero) periode 2015-2019 (Ditampilkan dalam mata uang Rp., kecuali ditampilkan secara khusus)

\begin{tabular}{|c|c|c|c|c|c|c|}
\hline \multirow{2}{*}{ NO } & \multirow{2}{*}{ INDIKATOR } & 2015 & 2016 & 2017 & 2018 & 2019 \\
\hline & & BOBOT & BOBOT & BOBOT & BOBOT & BOBOT \\
\hline 1 & $\mathrm{ROE}$ & 2 & 5,5 & 10 & 14 & 10 \\
\hline 2 & ROI & 3 & 3 & 4 & 4 & 4 \\
\hline 3 & Rasio Kas & 5 & 5 & 5 & 5 & 3 \\
\hline 4 & Rasio Lancar & 5 & 5 & 5 & 5 & 4 \\
\hline 5 & Collection Periods (CP) & 5 & 4,5 & 4,5 & 5 & 5 \\
\hline 6 & $\begin{array}{l}\text { Perputaran Persediaan } \\
\text { (PP) }\end{array}$ & 5 & 1,8 & 3 & 3,5 & 2,4 \\
\hline 7 & $\begin{array}{l}\text { Total Aset Turn Over } \\
\text { (TATO) }\end{array}$ & 2,5 & 3 & 2,5 & 3,5 & 2,5 \\
\hline 8 & Rasio TMS terhadap TA & 10 & 10 & 7,25 & 7,25 & 7,25 \\
\hline & AKUMULASI BOBOT & 37,5 & 37,8 & 41,25 & 47,25 & 38,15 \\
\hline & TOTAL SKOR & 53,57 & 54,00 & 58,93 & 67,50 & 54,50 \\
\hline & NGKAT KESEHATAN & $\begin{array}{l}\text { KURANG } \\
\text { SEHAT }\end{array}$ & $\begin{array}{l}\text { KURANG } \\
\text { SEHAT }\end{array}$ & $\begin{array}{l}\text { KURANG } \\
\text { SEHAT }\end{array}$ & SEHAT & $\begin{array}{l}\text { KURANG } \\
\text { SEHAT }\end{array}$ \\
\hline & KATEGORI & BBB & BBB & BBB & $\mathbf{A}$ & BBB \\
\hline
\end{tabular}

Penilaian kinerja keuangan PT Pindad (Persero) periode 2015-2019 berdasarkan (KEP-100/MBU/2002) menunjukkan hasil yang fluktuatif. Kita dapat tinjau dari perolehan akumulasi bobot PT Pindad (Persero) tahun 2015, diperoleh hasil 37,5 dengan total skor 53,57, dari hal tersebut perusahaan dinilai Tidak Sehat (BBB) dalam aspek keuangannya. Di tahun 2016, PT Pindad (Persero) mengalami kenaikan hingga perolehan akumulasi bobot sebesar 37,8 dengan total skor 54,00, di tahun ini perusahaan tetap berada pada tingkat kesehatan keuangan yang Tidak Sehat kategori BBB. Beralih ke tahun 2017, PT Pindad (Persero) kembali mengalami peningkatan hingga akumulasi bobot yang diperoleh sebesar 41,25 dengan total skor 58,93 (Kurang Sehat kategori BBB). Pada tahun 2018, perusahaan berhasil meningkatkan tingkat kesehatannya menjadi Sehat kategori A dengan perolehan akumulasi bobot sebesar 47,25 dan total skor 67,50, namun peningkatan di tahun 2018 tidak berlanjut, perusahaan kembali mengalami penurunan tingkat kesehatan hingga masuk pada jenjang Kurang Sehat kategori BBB, hal ini disebabkan karena perolehan akumulasi bobot sebesar 38,15 dan total skor 54,50.

\section{Penutup}

Berdasarkan rumusan masalah penelitian, pengolahan data serta pembahasan hasil penelitian dalam rangka melakukan penilaian tingkat kesehatan kinerja keuangan perusahaan BUMN bidang 
Industri Pertahanan (Indhan) Indonesia periode 2015-2019, kesimpulan yang diperoleh ialah sebagai berikut.

1) Hasil analisis penilaian tingkat kesehatan kinerja keuangan PT Dahana (Persero) periode 2015-2019 berdasarkan (KEP-100/MBU/2002) menunjukkan bahwa perusahaan memperoleh tingkat kesehatan keuangan "Sehat" kategori AA yang stabil pada tahun 2015 hingga 2018, sedangkan pada tahun 2019 tingkat kesehatan keuangan perusahaan turun pada peringkat "Sehat" kategori A.

2) Hasil analisis penilaian tingkat kesehatan kinerja keuangan PT Industri Telekomunikasi Indonesia (Persero) periode 2015-2019 berdasarkan (KEP-100/MBU/2002) menunjukkan bahwa perusahaan memperoleh tingkat kesehatan keuangan "Kurang Sehat" kategori B pada tahun 2015 hingga 2016, kemudian pada tahun 2017 meningkat menjadi "Kurang Sehat" kategori BB, dan pada tahun 2018 hingga 2019 mengalami penurunan menjadi "Tidak Sehat" kategori CCC.

3) Hasil analisis penilaian tingkat kesehatan kinerja keuangan PT Pindad (Persero) periode 2015-2019 berdasarkan (KEP-100/MBU/2002) menunjukkan bahwa perusahaan memperoleh tingkat kesehatan keuangan "Kurang Sehat" kategori BBB pada tahun 2015 hingga 2017, kemudian meningkat pada tahun 2018 menjadi "Sehat" kategori A, dan pada tahun 2019 mengalami penurunan menjadi "Kurang Sehat" kategori BBB.

\section{Daftar Pustaka}

Azzahra, S. F. (2017): Tugas Akhir berjudul "Analisis Kinerja Kenangan Perusabaan BUMN Sektor Pertambangan Yang Terdaftar Di Bursa Efek Indonesia Periode 2012-2016", 7-20.

Baridwan, Z. (2015): Intermediate Accounting. Yogyakarta: BPFE-Yogyakarta (Anggota IKAPI No.008).

Baskara, P. C., \& Rahyuda, H. (2016): Jurnal yang berjudul "Penilaian Tingkat Kesehatan Kenangan PT Pegadaian (Persero) Bedasarkan Keputusan Menteri BUMN No: (KEP-100/MBU/2002)". 5-12.

Fahmi, I. (2012): Analisis Kinerja Kenangan (Vol. Cetakan ke-1). Bandung: Alfabeta.

Harahap, Y. (2016). Hukum Perseroan Terbatas. Jakarta: Sinar Grafika.

Kasmir. (2010). Pengantar Manajemen Keuangan (I, Cetakan ke-2 ed.). Jakarta: Kencana.

Kementerian Pertahanan RI. (2019). WIRA Media Informasi Kementerian Pertahanan Edisi Khusus Khusus HUT TNI ke-74 berjudul "Eksistensi TNI Dalam Menghadapi Ancaman Militer dan Nir Militer Multidimensional Di Era Milenial". 39-45

Kementerian BUMN RI. (2002). Keputusan Menteri Badan Usaha Milik Negara Nomor (KEP100/MBU/2002) Tentang Penilaian Tingkat Kesebatan Badan Usaha Milik Negara. 1-27.

Lestari, E. K. (2016). Skripsi yang berjudul "Analisis Penilaian Tingkat Kesehatan BUMN Pada PT Taspen Tabun 2012-2014".

Mawarni, S. A. (2016). Jurnal yang berjudul "Analisis Penilaian Tingkat Kesehatan Badan Usaba Milik Negara (BUMN) Jasa Kenangan Bidang Usaba Perasuransian dan Jasa Penjaminan Periode 20142015". Diambil dari ejournal.adbisnis.fisip-unmul.ac.id

Munawir, S. (2007). Analisa Laporan Kenangan (XIV, Juli 2007 ed.). Yogyakarta: Liberty Yogyakarta.

Pemerintah Republik Indonesia. (2012). Undang-Undang Republik Indonesia Nomor 16 Tabun 2012 
Tentang Industri Pertahanan. Pemerintah Republik Indonesia. (2002): Undang-Undang Republik Indonesia Nomor 3 Tahun 2002 Tentang Pertahanan Negara.

PT Dahana. (2016). Laporan Kuangan Tabunan PT Dahana (Persero) Tabun 2015. PT Dahana (Persero). Diambil dari www.dahana.id

PT Dahana. (2017). Laporan Kuangan Tabunan PT Dahana (Persero) Tabun 2016. PT Dahana (Persero). Diambil dari www.dahana.id

PT Dahana. (2018). Laporan Kuangan Tabunan PT Dahana (Persero) Tabun 2017. PT Dahana (Persero). Diambil dari www.dahana.id

PT Dahana. (2019). Laporan Kuangan Tabunan PT Dahana (Persero) Tabun 2018. PT Dahana (Persero). Diambil dari www.dahana.id

PT Dahana. (2020). Laporan Kuangan Tabunan PT Dabana (Persero) Tabun 2019. PT Dahana (Persero). Diambil dari www.dahana.id

PT INTI. (2016). Laporan Kuangan Tahunan PT Industri Telekomunikasi Indonesia (Persero) Tahun 2015. PT INTI (Persero). Diambil dari www.inti.co.id

PT INTI. (2017). Laporan Kuangan Tabunan PT Industri Telekomunikasi Indonesia (Persero) Tabun 2016. PT INTI (Persero). Diambil dari www.inti.co.id

PT INTI. (2018). Laporan Kuangan Tahunan PT Industri Telekomunikasi Indonesia (Persero) Tabun 2017. PT INTI (Persero). Diambil dari www.inti.co.id

PT INTI. (2019). Laporan Kuangan Tabunan PT Industri Telekomunikasi Indonesia (Persero) Tabun 2018. PT INTI (Persero). Diambil dari www.inti.co.id

PT INTI. (2020). Laporan Kuangan Tahunan PT Industri Telekomunikasi Indonesia (Persero) Tahun 2019. PT INTI (Persero). Diambil dari www.inti.co.id

PT Pindad. (2016). Laporan Kuangan Tabunan PT Pindad (Persero) Tabun 2015. PT Pindad (Persero). Diambil dari www.pindad.com

PT Pindad. (2017). Laporan Kuangan Tabunan PT Pindad (Persero) Tabun 2016. PT Pindad (Persero). Diambil dari www.pindad.com

PT Pindad. (2018). Laporan Kuangan Tabunan PT Pindad (Persero) Tabun 2017. PT Pindad (Persero). Diambil dari www.pindad.com

PT Pindad. (2019). Laporan Kuangan Tahunan PT Pindad (Persero) Tabun 2018. PT Pindad (Persero). Diambil dari www.pindad.com

PT Pindad. (2020). Laporan Kuangan Tabunan PT Pindad (Persero) Tabun 2019. PT Pindad (Persero). Diambil dari www.pindad.com

Prasetyo, B., Permatasari, dkk. (2019, Februari 22). Jenis-jenis Badan Usaha dan Karakteristiknya. Diakses pada bulan Februari tanggal 25 tahun 2020, dari Hukum Online :https://m.hukumonline.com/klinik/detail/ulasan/lt4f51947253585/jenis-jenis-badanusaha-dan-karakteristiknya/

Sahri, \& dkk. (2016). Pelaporan Keuangan Perusabaan Dagang. Jakarta: Kementerian Pendidikan dan Kebudayaan, Direktorat Jenderal Guru dan Tenaga Kependidikan 2016. 
Angga Nugraha, Tjetjep Djuwarsa, Ine Mayasari

Saputro, F. G. (2014). Skripsi berjudul "Analisis Kinerja Kenangan Perusahaan BUMN Bidang Konstruksi Yang Terdaftar Di Bursa Efek Indonesia Periode 2010-2013".

Sugiyono. (2017). Metode Penelitian Kuantitatif, Kualitatif, dan R\&D (XXVI, Oktober 2017 ed.). Bandung, Jawa Barat, Indonesia: Penerbit Alfabeta. 